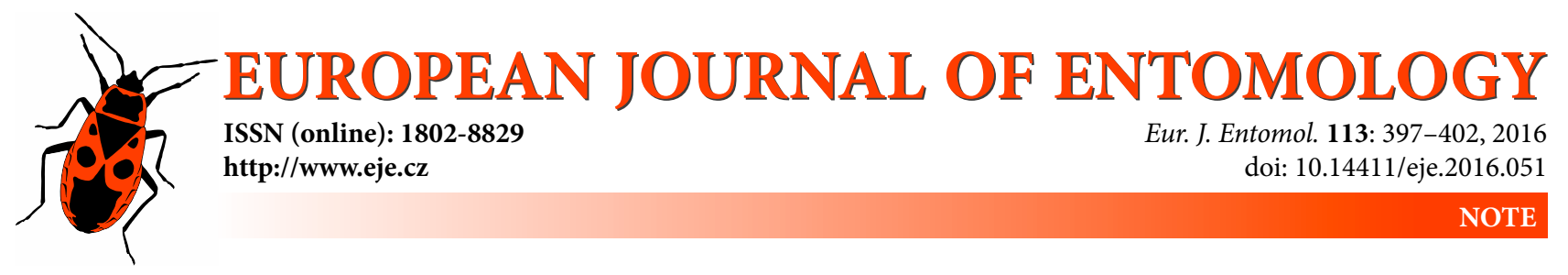

\title{
Tettigoniidae (Orthoptera) ovipositing in old galls of Dryocosmus kuriphilus (Hymenoptera: Cynipidae)
}

\author{
Giuliano CERASA and Bruno MASSA
}

Department of Agriculture and Forest Sciences, University of Palermo, Viale Scienze bd 5A, 90128 Palermo, Italy; e-mails: giulianocerasa@alice.it, bruno.massa@unipa.it

Key words. Hymenoptera, Cynipidae, gall-successor, Orthoptera, Tettigoniidae, bush-crickets, oviposition, biology, Italy

\begin{abstract}
This paper presents biological notes on two species of Orthoptera: Tettigoniidae that emerged from old spongy-woody galls of Dryocosmus kuriphilus Yasumatsu, 1951 collected in Sicily (Italy) in April 2015: Leptophyes sicula Kleukers, Odé et Fontana, 2010 (Phaneropterinae) and Cyrtaspis scutata (Charpentier, 1825) (Meconematinae). Between the end of April and the first few days of May a total of 30 neanids emerged from the galls, were reared and their life-cycle recorded. While $L$. sicula laid eggs in groups, $C$. scutata laid single eggs inside the galls; both species in a few years have adapted to exploiting this new shelter for egg laying. No interaction with the gall inducing insect was noted.
\end{abstract}

\section{INTRODUCTION}

Galls are induced by physical-chemical interactions between plants and organisms, such as insects, mites, nematodes, fungi, bacteria and viruses (Sugiura \& Yamazaki, 2009). Galls are adaptive in that they provide the inducers with nutritious tissues and sometimes shelter from natural enemies (Price et al., 1987). Gallinducers are referred to as "ecosystem engineers" because the physical-chemical alterations they induce in plant organs in the form of galls are habitats or resources for other organisms (Sugiura \& Yamazaki, 2009). Galls indeed are important resources not only for the gall-inducers, but also for other organisms, generally classified as either: parasitoids, hyperparasitoids, inquilines, cecidophages, predators, successors or symbionts (Sugiura \& Yamazaki, 2009).

Galls induced by Dryocosmus kuriphilus Yasumatsu, 1951 on Castanea sativa Miller, 1768 remain on the plant for months, sometimes years (Torrente-Pérez \& Fernández-López, 2015) after the emergence of the gall-inducer, parasitoids and inquilines, and provide other insects with shelter and vital space. Successors are secondary users of galls (Mani, 1964) and include spiders, pseudoscorpions, millipedes, beetles, ants, etc. (Cussigh, 1992; Sugiura \& Yamazaki, 2009), which use the gall as shelter or for laying eggs, among which there are also grasshoppers (Fischer, 1853; Fitsch, 1880; Chopard, 1938; Harz, 1957, 1984; Kleukers et al., 1997; Fontana et al., 2002; Blommers, 2008; Massa et al., 2012). As there are few publications on this sort of association involving grasshoppers this paper presents a description of the life cycles of two species of Orthoptera that were recorded emerging from old galls of $D$. kuriphilus.

\section{MATERIALS AND METHODS}

Table 1 lists localities and the dates on which D. kuriphilus galls were collected from three sites in Sicily. Only the old spongy-woody galls induced by Cynipidae were collected (Fig. 1E) over a period of two years. Overall, ca. 1000 galls were collected. These galls were kept at room temperature in a laboratory at the University of Palermo and the parasitoids and other insects that emerged were collected. Most of the insects were preserved and mounted, but the Orthoptera were transferred to small plastic containers covered by tulle (Fig. 1A and C). A small plug of wet cotton wool was glued to the inside top of the container to provide the insects with water; water was added when necessary by means of a syringe (Fig. 1B and D). Food provided was young chestnut Castanea sativa leaves, leaves of Sonchus oleraceus L., lettuce, young leaves of summer squash, apple peelings, and crumbled corn flakes and fish food.

As one of the successor species was thought to be insectivorous it was provided with prey, by placing them inside the containers; prey consisted of larvae and adults of moths, Hymenopteran parasitoids and Cynipidae. Every 4-5 days the containers were cleaned and all remnants of food removed to guarantee hygiene and prevent buildup of mould.

Table 1. List of localities and dates on which the galls of Dryocosmus kuriphilus were collected.

\begin{tabular}{|c|c|}
\hline Location (Province) GPS coordinates & Date of collection \\
\hline $\begin{array}{l}\text { Camaro (Messina) } \\
38^{\circ} 11^{\prime} 57.41^{\prime \prime} \mathrm{N}, 15^{\circ} 29^{\prime} 40.60^{\prime \prime} \mathrm{E} \\
38^{\circ} 11^{\prime} 54.74^{\prime \prime} \mathrm{N}, 15^{\circ} 29^{\prime} 40.99^{\prime \prime} \mathrm{E}\end{array}$ & 21.iv.2015 \\
\hline $\begin{array}{l}\text { Favarella (Messina) } \\
\quad 38^{\circ} 11^{\prime} 45.51^{\prime \prime} \mathrm{N}, 15^{\circ} 28^{\prime} 22.31^{\prime \prime} \mathrm{E}\end{array}$ & 21.iv.2015 \\
\hline $\begin{array}{l}\text { Musolino (Messina) } \\
38^{\circ} 11^{\prime} 32.50^{\prime \prime} \mathrm{N}, 15^{\circ} 29^{\prime} 4.02 \text { "E } \\
38^{\circ} 11^{\prime} 55.433^{\prime \prime}, 15^{\circ} 29^{\prime} 22.42 \text { "E } \\
38^{\circ} 11^{\prime} 52.40^{\prime \prime} \mathrm{N}, 15^{\circ} 29^{\prime} 19.18^{\prime \prime} \mathrm{E}\end{array}$ & 21.iv.2015 \\
\hline
\end{tabular}



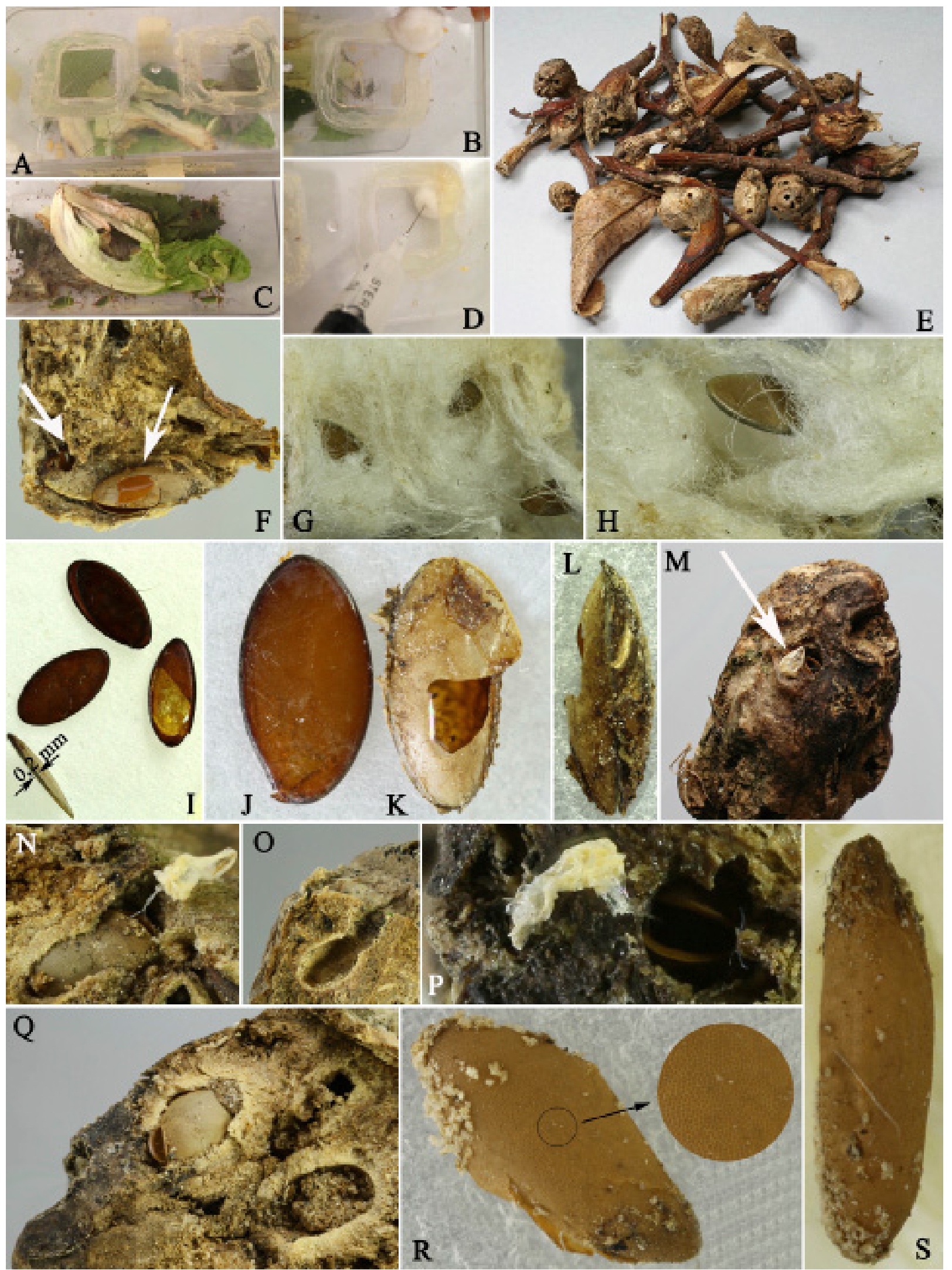

Fig. 1. Details of the cages in which the galls of Dryocosmus kuriphilus containing eggs of the successors Leptophyes sicula and Cyrtaspis scutata were kept $(A, C)$. Rearing containers $(B, D)$ showing top cover of container and the plug of cotton wool injected with water using a syringe. (E) Old spongy-woody galls of $D$. kuriphilus. (F) Eggs of $L$. sicula laid in crevices in the walls of old galls. (G-H) Eggs of $L$. sicula laid on the cotton wool attached to the cover of the container. (I) Details of the eggs extracted from the cotton wool. (J-K) Comparison of the eggs of $L$. sicula laid in the container $(J)$ and those obtained from galls $(K)$. (L) Side of an egg laid inside a gall. (M) Eggs of $C$. scutata individually laid inside the larval chamber of $D$. kuriphilus. (M, N, P) Silken pupal remains indicating an emerging $C$. scutata. (N, Q) Sections of galls showing the egg of $C$. scutata. (O) Larval chamber of $C$. scutata. (R-S) Egg of $C$. scutata extracted from a gall magnified to show its reticulate surface. (S) Side view of same egg. 

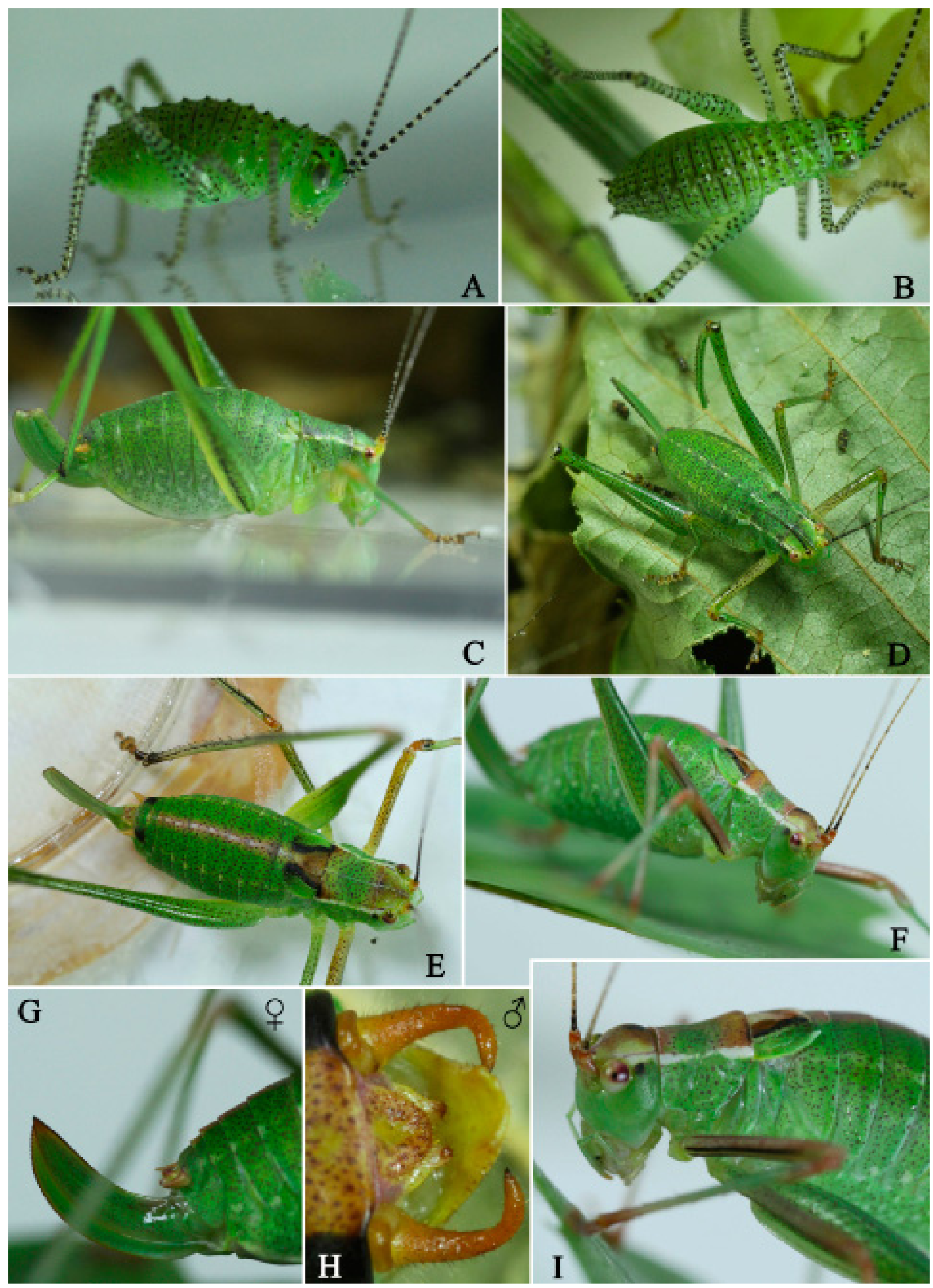

Fig. 2. Nymphal instars of Leptophyes sicula. A-B: 10th May 2015 (first-instar nymph); C-D: 6th June 2015; E-G: 20 th June 2015 (adult female and details of ovipositor); H-I: 6th June 2015 (adult male and details of cerci). 

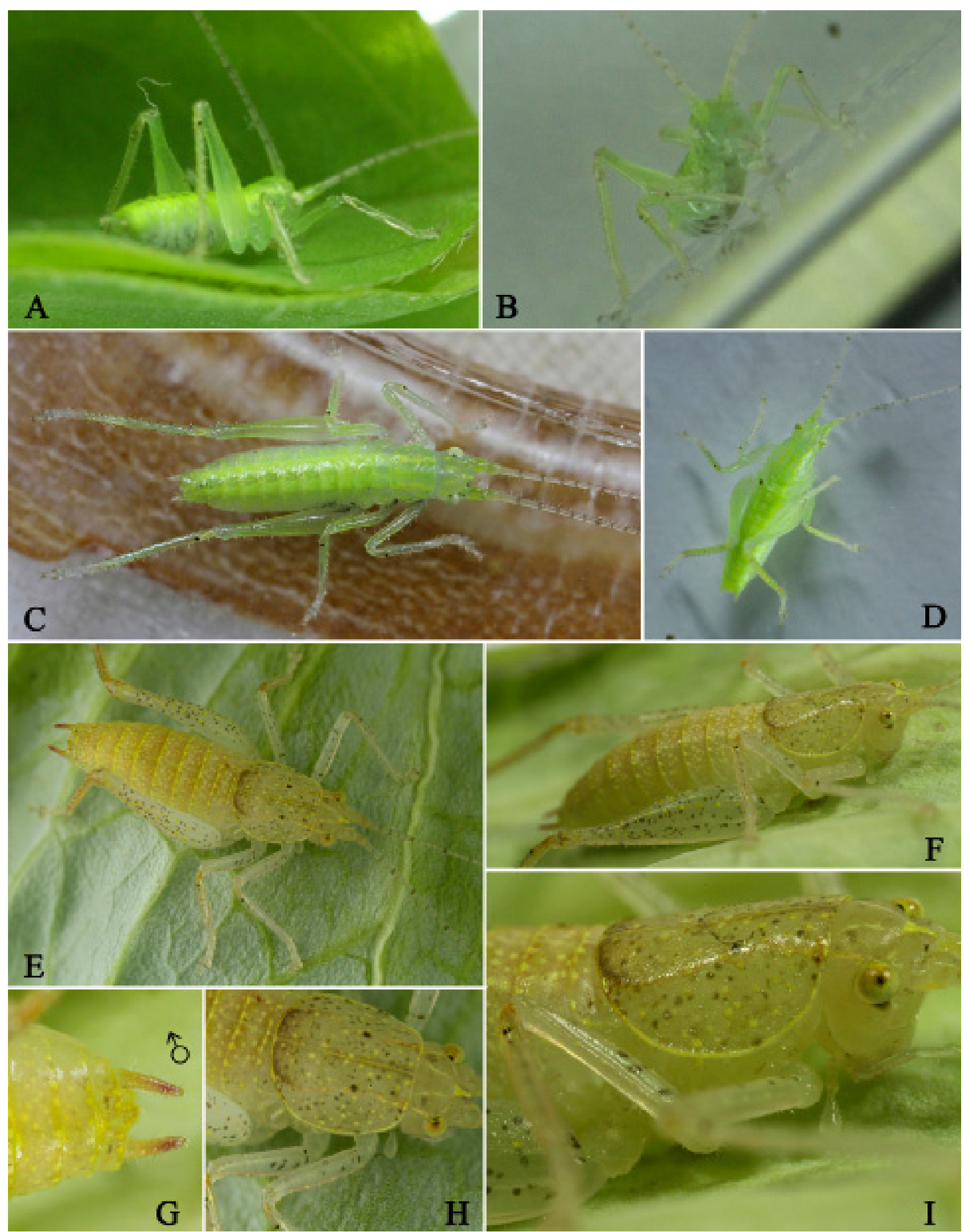

Fig. 3. Nymphal instars of Cyrtaspis scutata. A-B: 10th May 2015 (first-instar nymph); C: 23th May 2015 (second-instar nymph); D: 20th June 2015 (third-instar nymph); E-I: 8th August 2015 (adult male characteristics).

All the specimens were examined under a Wild-Heerbrugg M8 stereomicroscope. Some specimens (both galls and insects) were photographed using a Canon 7D digital camera provided with a macro lens Canon MP-E $65 \mathrm{~mm}$ and photographs were integrated using the freeware CombineZP (Hadley, 2011). In addition, we measured the length and breadth of the ovipositor of Orthoptera that emerged from galls, using specimens preserved in museum collections. Measurements were taken using the soft- 
ware Optika Vision Pro. Samples are preserved in the collections of the Department of Agriculture and Forest Sciences, University of Palermo.

\section{RESULTS AND DISCUSSION}

The insects that emerged from the galls were mainly Coleoptera Anobiidae of the genus Dryophilus Chevrolat, 1832; in addition, ca. 30 neanids of Orthoptera Ensifera belonging to two species emerged between the 27th April and 2nd May 2015.

One of them was Leptophyes sicula Kleukers, Odé et Fontana, 2010 (Tettigoniidae: Phaneropterinae). The adult laid groups of eggs in crevices inside the gall (Fig. 1F). The neanid emerged from an opening in the side of an egg (Fig. 1F). The first adults (male and female) emerged on 26.v.2015, one month after hatching and after an unknown number of moults (only three recorded, which occurred on 14.v.2015, 28.v.2015 and 12.vi.2015, respectively, during the night). It was difficult to recover their exuviae as these are eaten by the insects. During these nocturnal moults the insects were suspended from the top cover of the container; moulting lasted between 30 and $40 \mathrm{~min}$.

Upon reaching maturity, they mated and the female laid eggs on the cotton wool attached to the lid of the container (Fig. $1 \mathrm{G}$ and $\mathrm{H}$ ). While these flat eggs were elliptical in shape, were brown-amber colour, measured $3.5 \times 1.9 \mathrm{~mm}$, and resulted to be very flat $(0.2 \mathrm{~mm})$ (Fig. 1I and J), those found inside the galls of D. kuriphilus were clearer and not so flat $(0.7 \mathrm{~mm})$ (Fig. $1 \mathrm{~K}$ and L), probably due to the growth of the embryo. Eggs inside galls cannot be seen from outside, so it was necessary to open the galls.

Fig. 2 shows some nymphal instars of this insect, whose diagnostic characteristics are small black spots all over the body; in the first instar these spots are few and there are some markings in one or two lines on each tergite (Fig. 2A and B), later the markings are smaller and closer. Males and females of $L$. sicula reared in the same containers did not eat or attack one another. This is a phytophagous species, endemic to Sicily and discovered only recently (Kleukers et al., 2010), but previously considered as $L$. punctatissima (Bosc, 1791), a widespread European species associated with broadleaved trees and small bushes. It has a springsummer phenology (Massa et al., 2012).

The other species that emerged from eggs laid inside galls of $D$. kuriphilus was Cyrtaspis scutata (Charpentier, 1825) (Tettigoniidae: Meconematinae). It laid single eggs that occupied the entire empty larval chamber of the Cynipid (Fig. 1N and Q). Eggs are elliptical, light brown with a finely reticulated surface (Fig. 1R and $\mathrm{S}$ ), they measure $3 \times 1.5 \mathrm{~mm}$ and are $0.8 \mathrm{~mm}$ deep. In this case, the presence of eggs inside a gall is indicated by the presence of silken remains protruding from the external wall of the gall (Figs 1M, 1N and 1P). The first-instar nymph emerges from a hole in the egg next to the wall of the gall and as a result the margins of the egg shell curve outwards (Fig. 1P).

We recorded only one moult on 9.vii.2015, probably due to the small size of the insect. The first adult emerged on 8.viii.2015. Fig. 3 shows some of the instars of C. scutata, whose diagnostic characteristic is a small black marking on the outside of the proximal part of its tibiae, well visible against the green coloured body (Fig. 3A-C). In Italy C. scutata is a common species with a summer-autumn phenology and over winters as an adult. Oddly, this apterous species removes its faeces by using it's hind legs to push them away. This behaviour is regularly observed in flightless Orthoptera Pamphagidae (pers. obs.).

The only European Orthopterans previously known to occupy galls were Conocephalus fuscus (F., 1793) (Tettigoniidae: Conocephalinae) (obtained from galls induced by unidentified flies on reeds), L. punctatissima (Tettigoniidae: Phaneropterinae), $C$. scutata, Meconema thalassinum (De Geer, 1773) and M. meridi- onale (Costa, 1860) (Tettigoniidae: Meconematinae), obtained from galls of Biorhiza pallida (Olivier 1791), Andricus hungaricus (Hartig 1843), Andricus kollari (Hartig, 1843) and Andricus coriarius (Hartig, 1843) (Hymenoptera: Cynipidae), in Great Britain, Germany, France, Croatia, Denmark, Netherland and Italy (Fischer, 1853; Fitsch, 1880; Chopard, 1938; Harz, 1957, 1984; Kleukers et al., 1997; Fontana et al., 2002; Blommer, 2008; Massa et al., 2012). These species generally lay single eggs in small holes in gall tissues (Figs M-Q). The ovipositor of $L$. sicula is $1.9 \pm 0.1(\min 1.7, \max 2.1) \mathrm{mm} \times 0.09 \pm 0.01(\min 0.08, \max$ $0.1)(\mathrm{n}=6) \mathrm{mm}$ and that of C. scutata $0.6 \pm 0.07(\min 0.5$, $\max$ $0.7) \mathrm{mm} \times 0.13 \pm 0.06(\min 0.09, \max 0.17) \mathrm{mm}(\mathrm{n}=6)$. Thus, they are very small compared to the emerging hole in the galls (1.8-2.4) they occupy; however, Phaneropterinae before laying produce or widen a hole with their mandibles (Chopard, 1938; Massa \& Rizzo, 1998).

C. scutata is insectivorous, probably specializing on small parasitic insects living on plants (Massa et al., 2012). We were able to confirm that $C$. scutata feeds on larvae and adults of small moths, immobilizing them with the help of the spines on its forelegs. It consumes entire larvae except for the cephalic capsule. It did not feed on the Hymenoptera, including the Cynipidae provided, probably due to their hard cuticle.

\section{CONCLUDING REMARKS}

The presence in Sicily of accidentally imported D. kuriphilus was confirmed for the first time in May 2010 in some chestnut woods on Mt. Etna (Longo \& Sidoti, 2011; EPPO, 2011); later it spread to other areas in Sicily (province of Messina) (Cerasa, 2015). It is likely that the species of Orthoptera and Coleoptera we recorded as successors inside galls of $D$. kuriphilus probably previously used other species of autochthonous galls of Cynipidae and found the galls of $D$. kuriphilus suitable for egg laying or over-wintering. We presume that it also lays eggs in other oak galls belonging to the subgenus Quercus, sections Quercus and Cerris, like Andricus kollari, Andricus coriarius and Synophrus politus Hartig 1843, which are rather common and suitable for the egg laying of bush-crickets. In a matter of a few years an insect community of successors has successfully colonized galls of newly arrived species in chestnut woods. However, the exploitation of the gall by successors does not cause any damage to the gall-inducer, because the galls exploited are old and gall-inducers have already emerged. Thus, egg-laying inside galls by the two species of Orthoptera reported here should not affect the spread of D. kuriphilus. We can also exclude the possibility of C. scutata being a predator of Cynipidae and a biocontrol agent of the non-native species, $D$. kuriphilus. In addition, other successors are saprophagous or detritivorous and do not adversely affect the biological cycle of $D$. kuriphilus.

ACKNOWLEDGEMENTS. Material was collected during monitoring of the parasitoid Torymus sinensis, released by the Servizio Fitosanitario Regionale in 2013 and 2014 in order to control Dryocosmus kuriphilus (coordinator for the University: Virgilio Caleca). We also thank J.J. Borg for revision of the text.

\section{REFERENCES}

Blommers L.H.M. 2008: Pemphredon austriaca (Hymenoptera: Crabronidae) and various other insect species as inhabitants of deserted galls. - Entomol. Ber. 68: 170-174.

Cerasa G. 2015: Cynipidae, Curculionoidea e Cecidomyiidae galligeni in Sicilia: Stato delle conoscenze e nuovi dati. $\mathrm{PhD}$ Thesis, University of Palermo, $118 \mathrm{pp}$. 
ChOpard L. 1938: La biologie des Orthoptères. Lechevallier, Paris, $541 \mathrm{pp}$.

Cussigh F. 1992: Osservazioni su Curculio vicetinus Cussigh, un inquilino delle galle fogliari di Pediaspis aceris Gmelin modificate da Dichatomus acerinus Förster (Coleoptera: Curculionidae). - Mem. Soc. Entomol. Ital. 70: 181-206.

EPPO 2011: First report of Dryocosmus kuriphilus in Sicily (IT). - EPPO Report. Serv. 2: 11.

Fischer L.H. 1853: Orthoptera Europaea. G. Engelmann, Lipsiae, $454 \mathrm{pp}$.

FIтсн E.A. 1880: Insects bred from Cynips kollari galls. - Entomologist 18: 252-263.

Fontana P., Buzzetti F. M., Cogo A. \& Odé B. 2002: Guida al riconoscimento e allo studio di cavallette, grilli, mantidi e insetti affini del Veneto. Guide Natura/1. Museo Naturalistico Archeologico, Vicenza, $592 \mathrm{pp}$.

HadLey A. 2011: Combine ZP. URL: http://hadleyweb.pwp.blueyonder.co.uk (last accessed 12 Sep. 2014).

Harz K. 1957: Die Geradflügler Mitteleuropas. G. Fischer, Jena, $494 \mathrm{pp}$.

HARZ K. 1984: Eiablage von Laubheuschrecken (Ensifera) in Gallen. - Articulata 2(4): 91.

Kleukers R.M.J.C., van NieuKerken E.J., Odé B., Willemse L. \& VAN WINGERDEN W. 1997: De sprinkhanen en krekels van Nederland (Orthoptera). Nederlandse Fauna I. Nationaal Natuurhistorisch Museum, KNNV Uitgeverij and EIS Nederland, Leiden, $415 \mathrm{pp}$.
Kleukers R.M.J.C., Odé B. \& Fontana P. 2010: Two new cryptic Leptophyes species from southern Italy (Orthoptera: Tettigoniidae). - Zootaxa 2506: 26-42.

Longo S. \& Sidoti A. 2011: Spreading in Sicily of the chestnut gall wasp and its indigenous parasitoids. In: Atti XXIII Congr. Naz. Ital. Entomol., 13-16 June 2011, Genova, Italy. p. 132. [in Italian].

Mani M.S. 1964: Ecology of Plant Galls. W. Junk, The Hague, $434 \mathrm{pp}$.

Massa B. \& Rizzo M.C. 1998: Osservazioni sull'ovideposizione di Phaneroptera nana Fieber 1853 (Orthoptera: Tettigoniidae). - Phytophaga 8: 49-56.

Massa B., Fontana P., Buzzetti F.M., Kleukers R.M.J.C. \& OdÉ B. 2012: Fauna d'Italia. 48. Orthoptera. Calderini, Milano, $563+$ CCXIV + cd rom.

Price P.W., Fernandes G.W. \& Waring G.L. 1987: Adaptive nature of insect galls. - Environ. Entomol. 16: 15-24.

SUGIURA S. \& YAMAZAKI K. 2009: Gall-attacking behavior in phytophagous insects, with emphasis on Coleoptera and Lepidoptera. - Terr. Arthropod. Rev. 2: 41-61.

Torrente-Pérez R. \& Fernández-López J. 2015: Medidas contra a avespa chinesa do castiñeiro (Dryocosmus kuriphilus). Xunta de Galicia, Consellería do Medio Rural o do Mar, Santiago de Compostela, $23 \mathrm{pp}$.

Received March 9, 2016; revised and accepted April 4, 2016 Published online May 17, 2016 